\title{
Fetal Bovine Serum
}

National Cancer Institute

\section{Source}

National Cancer Institute. Fetal Bovine Serum. NCI Thesaurus. Code C113696.

The serum blood fraction obtained from cow fetuses and used as a component of growth medium. 